\title{
Effect of Coated Urea with Humic-Calcium on Transformation of Nitrogen in Coastal Sandy Soil: A Soil Column Method
}

\author{
Sulakhudin, Abdul Syukur, Dja'far Shiddieq and Triwibowo Yuwono ${ }^{1}$ \\ Received 29 November 2009 / accepted 8 January 2010
}

\begin{abstract}
Effect of Coated Urea with Humic-Calcium on Transformation of Nitrogen in Coastal Sandy Soil: A Soil Column Method (Sulakhudin, A Syukur, D Shiddieq and T Yuwono): In coastal sandy soil, mainly nitrogen losses due to leaching resulted to low fertilizer efficiency. Slow-release $\mathrm{N}$ fertilizers are proposed to minimize these losses, and humic-calcium coated urea has been examined. A soil column method was used to compare the effects of coated urea with humic-calcium on transformation and leaching loss of $\mathrm{N}$ in coastal sandy soil. The experiment aid to compare two kinds sources of humic substances (cow manure and peat) which mixed with calcium as coated urea on transformation, vertical distribution and leaching $\mathrm{N}$ in coastal sandy soil. The concentration of humic-calcium coated urea i.e. $1 \%, 5 \%$ and $10 \%$ based on their weight. The results showed that urea coated with humic-calcium from cow manure (UCHM) and humic-calcium from peat (UCHP) increased the $\mathrm{N}$ total and available $\mathrm{N}$ in the soil and decreased leaching loss of $\mathrm{N}$ from the soil column. Compared to UCHP, UCHM in all concentration showed $\mathrm{N}$-nitrate higher than $\mathrm{N}$-ammonium on incubation length 2, 4 and 6 weeks. The $\mathrm{N}$ leached from a costal sandy soil with application coated urea with UCHM ranged from $21.18 \%$ to $23.72 \%$ of the total $\mathrm{N}$ added as fertilizer, for coated urea with UCHP they ranged between $21.44 \%$ and $23.25 \%$, whereas for urea (control) reached $29.48 \%$. Leaching losses of mineral $\mathrm{N}$ were lower when urea coated with UCHM compared to urea coated with UCHP or urea fertilizer. The study concluded that the UCHM is better than UCHP in decreasing $\mathrm{N}$ leached from coastal sandy soil.
\end{abstract}

Keywords: Coastal sandy soil, coated urea, humic-calcium, nitrogen

\section{INTRODUCTION}

Nitrogen is the most limiting nutrient for crop production in many regions of the world (Fageria 2009), especially in arid and semiarid regions (Sharifi et al. 1988). So it is very important to increase the growth of plants and their quality with improving nitrogen fertilizer. In addition, nitrogen fertilizers worldwide is estimated to be $9.09 \times 107 \mathrm{Mg} \mathrm{yr}^{-1}$ (International Fertilizer Industry Association 2006). Urea (U) is the predominant source of inorganic $\mathrm{N}$ fertilizer in agriculture throughout the world, accounting for $50 \%$ of the total world fertilizer $\mathrm{N}$ consumption (Cobena et al. 2008). Urea, when applied to soil, is hydrolyzed by urease to form $\mathrm{NH}_{4}{ }^{+}$ and is subsequently converted to nitrate by the action of nitrifying bacteria (Kiran and Patra 2003), which can be leached or denitrified (Patra et al. 2009). About $16.2 \%$ to $30.4 \%$ of the $\mathrm{N}$ leached from the sandy loam soil originated from the urea- $\mathrm{N}$ fertilizer (Zhou et al. 2006).

The excessive loss of $\mathrm{N}$ due to $\mathrm{NO}_{3}^{-}$leaching causes not only large economic and resource losses but also very serious environmental pollution $(\mathrm{Wu}$ and Liu 2008). One method of reducing fertilizer nutrients losses involves the use of slow- or controlled-release fertilizers (Wu et al. 2008). The control of fertilizer release keeps the fertilizer concentration at effective levels in the soil solution and releases the fertilizer when the plant most needs it (Al-Zahrani 1999). These fertilizers can be physically prepared by coating granules of

\footnotetext{
${ }^{1}$ Soil Department, Faculty of Agriculture, Gadjah Mada University. Flora Street No 1, Bulaksumur, Yogyakarta 55281, INDONESIA. Telp: +62-0274-548814

Corresponding author email: sulakhudin@gmail.com

J Trop Soils, Vol. 15, No. 1, 2010: 11-18

ISSN 0852-257X
} 
conventional fertilizers with various materials that reduce their dissolution rate (Tomaszewska et al. 2002). The release and dissolution rates of watersoluble fertilizers depend on the coating materials. The membrane materials developed can be divided into two main varieties, inorganic mineral and organic polymer (Zou et al. 2009).

Humic substances (Hs), as one of the organic macromolecule compounds, were made for membrane material. It can incorporate nitrogen into their structure either directly through chemical reactions or indirectly through microbial activities and subsequent decomposition of microbial biomass (Clinton et al. 1995). Humic acid made from low grade coal, such as lignite, has a long history of use as a fertilizer in combination with urea. It has been shown that lignite humic acid can increase crop yields and plant $\mathrm{N}$ use efficiency relative to urea-only treatments (Ahmed et al. 2006; Zheng 1991).

In general, negative charge in $\mathrm{Hs}$ is originated from dissociation of ion $\mathrm{H}$ from functional groups especially carboxyl and phenol. Approximately 85 to $90 \%$ negative charged are derived from those groups. The carboxyl and phenol from Hs, having similar negative charged, are not able to bond ion nitrate; therefore become easier subject to leaching. In order to bond the nitrate from urea with $\mathrm{Hs}$, the process needs cation, i.e. calcium to bridge functional humic group and ion nitrate. Existence of $\mathrm{Ca}$ in between humic and nitrate will create out sphere complex.

The cation $\mathrm{Ca}$ is selected because it has two positively charged and the bonding energy weaker but has strong bond not to be leach by irrigation. One of $\mathrm{Ca}$ positively charged aims to bond $\mathrm{NO}_{3}^{-}$, while the other positively charged will be bonded to oxygen of humic (Oviasogie and Okolo 2008). According to Huang and Schnitzer (1997), the bonding between $\mathrm{Ca}$ and Oxygen is $839 \mathrm{kcal} \mathrm{mol}^{-1}$ smaller than that of $\mathrm{Al}^{3+}, \mathrm{Fe}^{3+}$ and $\mathrm{Mg}^{2+}$ respectively are 1,793; 919; dan $912 \mathrm{kcal} \mathrm{mol}^{-1}$. The study in coastal sandy soil was performed to examine the effect of coated urea with several humic-calcium (hucalci) to transformation and reduction of leaching $\mathrm{N}$.

\section{MATERIALS AND METHODS}

\section{Study Site and Soil Preparation}

Surface soil samples $(0-40 \mathrm{~cm})$ were sampled from the Bugel coastal area in Panjatan Subdistrict, Kulon Progo District, Yogyakarta Special Province.
It is classified as a Typic Udicpsamment in the USDA system (USDA 2003). The collected samples were air-dried, crushed, and passed through a 2-mm sieve and preserved for analysis. The cow manure derived from veterinarian in Bugel, whilst peat from lake rawa pening in Ungaran. Selected physical and chemical properties of soil were determined using standard procedures. The soil texture was carried out using the International Pipette method. Particle density (Dp) was measured using Pycnometer. Bulk density (Db) was determined using Clod Saturation Method. Hydraulic conductivity was determined using Constant Head Permeameter Method. Distribution of soil pores was estimated using Pressure Plate Method and calculated based on $\mathrm{pF}$ value $(\mathrm{pF} 0,2.0,2.54$, 4.0, and 7.0). Porosity was estimated mathematically using equation $(=1-(\mathrm{Db} / \mathrm{Dp}))$ (Sarkar and Haldar 2005).

The $\mathrm{pH}$ of soil determined in a 1:2.5 soil: distilled water suspension and $\mathrm{KCl}$ using a glass electrode. Soil organic carbon was determined using Walkley and Black method. Soil CEC was determined by leaching $1 \mathrm{M}$ ammonium acetate buffer adjusted to pH 7.0 followed by steam distillation (Pansu and Jacques 2006). Soil available phosphorus was extracted with $\mathrm{NaHCO} 3(0.5 M)$ at $\mathrm{pH} 8.5$ and determined colorimetrically after treating with ammonium molybdate and stannous chloride at a wavelength of $660 \mathrm{~nm}$. Extraction of exchangeable $\mathrm{K}$, and $\mathrm{Ca}$ was done by the double acid method (Tan 1996). After extraction, the cations were measured using atomic absorption spectrophotometry (AA-6200 SHIMADZU). The HS extraction was carried out by the methods of Rocha et al. (1998). Carboxylic$\mathrm{COOH}$, phenolic-OH and total acidity of HS were determined using the method described by Pansu and Jacques (2006).

\section{The Production of Slow Released Urea}

To obtain Hs, manure and peat was air dried and added with $20 \mathrm{ml} \mathrm{KOH} 0.5 \mathrm{~N}$. Hucalci gained from Hs plus $\mathrm{CaCl}_{2} 0.5 \mathrm{M}$ is filtered used whatman 42 . The oven dry hucalci is powdered and mixed with starch at the rate of $1 \%$ (low), $5 \%$ (moderate) and $10 \%$ (high) concentration to obtain 6 combination of hucalci used as coating material of urea. The coating material was spread to the urea particles until the surface was cover homogeneously. Then the coated urea was dried. The $\mathrm{N}$ content of each coated was analyzed and the result is in Table 1. 
Table 1. The N content and rates of UCHM, UCHP and urea fertilizer.

\begin{tabular}{ccccc}
\hline No. & Type of fertilizer & $\begin{array}{c}\text { N content of fertilizer } \\
(\%)\end{array}$ & $\begin{array}{c}\text { Rate/column } \\
(\mathrm{g})\end{array}$ & $\begin{array}{c}\text { Total N/column } \\
(\%)\end{array}$ \\
\hline 1 & UCHM 1 \% & 43.92 & 0.38 & 0.62 \\
2 & UCHM 5 \% & 45.42 & 0.37 & 0.62 \\
3 & UCHM 10 \% & 41.10 & 0.41 & 0.62 \\
4 & UCHP 1\% & 43.17 & 0.39 & 0.62 \\
5 & UCHP 5\% & 42.39 & 0.40 & 0.62 \\
6 & UCHP 10\% & 43.32 & 0.39 & 0.62 \\
7 & Urea & 44.54 & 0.38 & 0.62 \\
\hline
\end{tabular}

\section{Experimental Design}

Completely randomized design (CRD) was performed to examine the effects of hucalci coated with urea $(\mathrm{UCH})$ on soil dynamic and leaching $\mathrm{N}$. The treatments consist of 6 kinds of $\mathrm{UCH}$, plus non coated urea as control, with three replications. The study was conducted in a greenhouse at $25 \pm 3^{\circ} \mathrm{C}$ using soil packed in a polyvinyl chloride (PVC) pipe (50 $\mathrm{cm}$ long by $6 \mathrm{~cm}$ i.d.). The pipe was split longitudinally into three pipes i.e. $0-10 \mathrm{~cm}, 10-30$ $\mathrm{cm}$ and $30-50 \mathrm{~cm}$. The three pipes were joined and taped to form a column. A nylon mesh was fixed at the bottom of each PVC tube. The soil was air-dried and passed through a 2-mm sieve. Then, each tube was packed with $2.8 \mathrm{~kg}$ sandy soil having a bulk density of $1.31 \mathrm{~g} \mathrm{~cm}^{-3}$, and the PVC tubes were fixed in a pot to collect the drainage water during irrigation. Each UCH fertilizer with the rates follows Table 1, were applied on the $5 \mathrm{~cm}$ soil surface and incubated for 2, 4, and 6 week length. In every three days, the columns were given with aquadest on the level between the field capacity and saturated condition. Three kinds of UCH consists of urea $(\mathrm{U})$, urea coated with hucalci from cow manure (UCHM) and urea coated with hucalci from peat (UCHP). At the end of each incubation periods soil was sampled to measure total $\mathrm{N}(0-50 \mathrm{~cm})$; avaibility $\mathrm{N}\left(\mathrm{NH}_{4}^{+}\right.$and $\mathrm{NO}_{3}{ }^{-}: 0-$ $10 \mathrm{~cm}, 10-30 \mathrm{~cm}$ and $30-50 \mathrm{~cm}$ ); $\mathrm{N}$ leached on drainage water. Analysis of variance (ANOVA) was used to test treatment effects whilst means of treatments were compared using Duncan's test.

\section{RESULTS AND DISCUSSION}

\section{The Characteristic of Coastal Sandy Soil and Hs}

Table 2 shows that the texture is sandy $(97.31 \%$ sand), and the bulk density $\left(1.89 \mathrm{~g} \mathrm{~cm}^{-3}\right)$ is considered high (Hazelton and Murphy 2007). Consequently porosity is high at $32.03 \%$ with drainage pore is also high $(29.12 \%)$. The capability of the coastal sandy soil to retain water is low the percentage of water fill pores very small $(0.66 \%)$. The water velocity of this soil is very fast appearing from the rate of soil hydraulic conductivity is very high $\left(134.7 \mathrm{~cm}\right.$ hour $\left.{ }^{-1}\right)$. Therefore the available water capacity (AWC) is very low $2.10 \%$.

The initial soil analysis showed that macro and micro nutrients are very low. The availability of nitrogen is dominated by nitrate $(4.26 \mathrm{ppm})$ form. The ammonium was only $0.7 \mathrm{ppm}$. The level of cation exchange capacity (CEC) is very low $(1.91 \mathrm{cmol}(+)$ $\mathrm{kg}^{-1}$ ). The soil reaction is considered neutral (soil $\mathrm{pH}$ 7.76). Although this soil is located in coastal area, it is not considered a sodic soil.

The high sand particles, porosity, drainage pores, and permeability with the low CEC of in this coastal sandy soil could support $\mathrm{N}$ leaching. Generally $\mathrm{NO}_{3}$ leached more rapidly from sandy than silt and clay soils. An average annual leaching rate of $63 \mathrm{~kg} \mathrm{NO}_{3}^{-}$ $-\mathrm{N} \mathrm{ha}{ }^{-1}$ was estimated for sandy soils as compared to $16 \mathrm{~kg} \mathrm{NO}_{3}^{-}-\mathrm{N} \mathrm{ha}^{-1}$ for heavier arable soils developed in loess (Neinder and Benbi 2008).

Table 3 shows that the Hs material extracted from cow manure $(26.23 \%)$ are not significantly 
Table 2. Some physical and chemical properties of the experimental soil at the beginning of the experiment.

\begin{tabular}{|c|c|c|}
\hline Soil properties & Value & Level \\
\hline \multicolumn{3}{|l|}{ Soil fractions $(\%)$} \\
\hline clay & 0.90 & - \\
\hline silt & 1.79 & - \\
\hline sand & 97.31 & - \\
\hline Texture class & sand & \\
\hline $\mathrm{pH} \mathrm{H}_{2} \mathrm{O}$ & 6.67 & Neutral* \\
\hline $\mathrm{pH} \mathrm{KCl}$ & 5.69 & Medium acid* \\
\hline $\mathrm{EC}(\mathrm{mS})$ & 0.20 & \\
\hline Total organic $\mathrm{C}(\%)$ & 0.08 & Very low* \\
\hline Organic matter $(\%)$ & 0.13 & Very low* \\
\hline Total N (\%) & 0.02 & Very low* \\
\hline $\mathrm{N}-\mathrm{NO}_{3}^{-}(\mathrm{ppm})$ & 4.26 & Very low* \\
\hline $\mathrm{N}-\mathrm{NH}_{4}^{+}(\mathrm{ppm})$ & 0.70 & Very low* \\
\hline $\mathrm{C} / \mathrm{N}$ & 8.00 & low* \\
\hline Available P (ppm) & 9.67 & Very low* \\
\hline Exchangeable $\mathrm{K}\left(\mathrm{cmol}(+) \mathrm{kg}^{-1}\right)$ & 0.17 & low* \\
\hline Exchangeable $\mathrm{Ca}\left(\mathrm{cmol}(+) \mathrm{kg}^{-1}\right)$ & 0.88 & Very low* \\
\hline $\mathrm{CEC}\left(\mathrm{cmol}(+) \mathrm{kg}^{-1}\right)$ & 1.91 & Very low* \\
\hline Bulk density $(\mathrm{Db})\left(\mathrm{g} \mathrm{cm}^{-3}\right)$ & 1.89 & - \\
\hline Particle density (Dp) $\left(\mathrm{g} \mathrm{cm}^{-3}\right)$ & 2.78 & - \\
\hline Porosity (\%) & 32.03 & Very high* \\
\hline Hydraulic conductivity $\left(\mathrm{cm}\right.$ hour ${ }^{-1}$ ) & 134.7 & Very quick* \\
\hline \multicolumn{3}{|l|}{ Distribution of soil pores } \\
\hline Total soil pores $(\%)$ & 31.85 & - \\
\hline Useless soil pores (\%) & 2.07 & - \\
\hline Usefull soil pores (\%) & 29.78 & - \\
\hline Water hold pores (\%) & 0.66 & - \\
\hline Drainage pores $(\%)$ & 29.12 & - \\
\hline Slow drainage pores ( $\%)$ & 1.71 & - \\
\hline Rapid drainage pores (\%) & 27.41 & - \\
\hline
\end{tabular}

Source *: Hazelton and Murphy (2007).

different than that of peat $(23.77 \%)$. In comparison with similar method Hs from cow manure and peat is higher than that from vermicompos and Cananeia island soil which contains $9.12 \%$ and $10.28 \%$ (Rocha et al. 1998). The result also showed that total acidity, functional carbolic and phenolic and the AWC of Hs from cow manure is not significantly different than those of peat.

\section{Transformation of Urea in Soil after Fertilization}

The Change in the distribution of $\mathrm{NH}_{4}{ }^{+} \mathrm{N}$ and $\mathrm{NO}_{3}-\mathrm{N}$ in the soil columns after several periods of 2 , 4, and 6 weeks of incubation is presented in Figure 1 and 2. For $\mathrm{NH}_{4}^{+}-\mathrm{N}$ (Figure 1), the distribution of $\mathrm{NH}_{4}^{+}-\mathrm{N}$ in various layers of the soil column under all type of fertilizer treatments at 2 weeks incubation was different with those at 4 and 6 weeks incubation periods. $\mathrm{NH}_{4}{ }^{+} \mathrm{N}$ in the upper layer $(0-10 \mathrm{~cm})$ of the soil column at 2 weeks incubation was lower than that in the deeper layers $(30-50 \mathrm{~cm})$, indicating higher proportion of the downward movement of $\mathrm{NH}_{4}{ }^{+} \mathrm{N}$ ions in the sandy soil. At 4 and 6 weeks incubation periods, the amount of $\mathrm{NH}_{4}^{+}-\mathrm{N}$ in all layers soil column was low (Figure 1), suggesting the high leaching loss of $\mathrm{NH}_{4}^{+}-\mathrm{N}$ from the sandy soil. Zhou et al. (2006) also found that about $16.2 \%$ of the total ammonium fertilizer applied to the soil column was leached from the sandy loam soil. It suggested that although soil colloids could adsorb $\mathrm{NH}_{4}{ }^{+}$ions, high concentrations of $\mathrm{NH}_{4}^{+}$ion cation could overload the adsorption capacity of this soil. The adsorption capacity in sandy soil was very low $(1.91 \mathrm{cmol}(+)$ $\mathrm{kg}^{-1}$, Table 2), due to the result that $\mathrm{NH}_{4}{ }^{+}$ions could be easily leached into the deeper layers of the sandy soil.

Compared to the control (U) with application of non coated urea, there was a trend of increasing in $\mathrm{NH}_{4}{ }^{+} \mathrm{N}$ in the soil column (Figure 1) on the 6 weeks incubation, especially treatment UCHM. Figure 1 shows also that to compare with other treatments the ammonium content is highest (3.15) on 2 weeks incubation period of $10 \%$ HCUM. This is probably because not all portion functional groups of $\mathrm{Hs}$ negatively charged bounded the calcium. The rest portion bounded the positively charged of anion. Those functional groups like phenolic-OH and carboxylic- $\mathrm{COOH}$ were able to capture and retain $\mathrm{NH}_{4}^{+}$. This positively charged $\mathrm{NH}_{4}{ }^{+}$is in turn adsorbed to the negatively charged sites of phenolic-OH and carboxylic-COOH compounds (Reeza et al. 2009). After 2 weeks incubation, $\mathrm{NH}_{4}^{+}-\mathrm{N}$ in the soil was significantly reduced, and $\mathrm{NO}_{3}^{-}-\mathrm{N}$ still high (Figure 2 ), suggesting the occurrence of the nitrification. 
Table 3. ANOVAs result of Hs extracted from cow manure and peat.

\begin{tabular}{lccccccc}
\hline No. & Material & $\begin{array}{c}\text { Total Acidity } \\
\left(\mathrm{cmol}(+) \mathrm{kg}^{-1}\right)\end{array}$ & $\begin{array}{c}-\mathrm{COOH} \\
\left(\mathrm{cmol}(+) \mathrm{kg}^{-1}\right)\end{array}$ & $\begin{array}{c}-\mathrm{OH} \\
\left(\mathrm{cmol}(+) \mathrm{kg}^{-1}\right)\end{array}$ & $\begin{array}{c}\text { AWC } \\
(\%)\end{array}$ & $\begin{array}{c}\text { Weight } \\
(\mathrm{gram})\end{array}$ & $\begin{array}{c}\text { Percentage } \\
(\%)\end{array}$ \\
\hline 1. & Cow manure & $5.45 \mathrm{a}$ & $0.72 \mathrm{a}$ & $4.73 \mathrm{a}$ & $3.34 \mathrm{a}$ & $2.63 \mathrm{a}$ & $26.32 \mathrm{a}$ \\
2. & Peat & $3.45 \mathrm{a}$ & $0.67 \mathrm{a}$ & $2.78 \mathrm{a}$ & $2.53 \mathrm{a}$ & $2.38 \mathrm{a}$ & $23.77 \mathrm{a}$ \\
\hline
\end{tabular}

Note: Values with similar letter are not significantly different $(\alpha \leq 0.05)$.

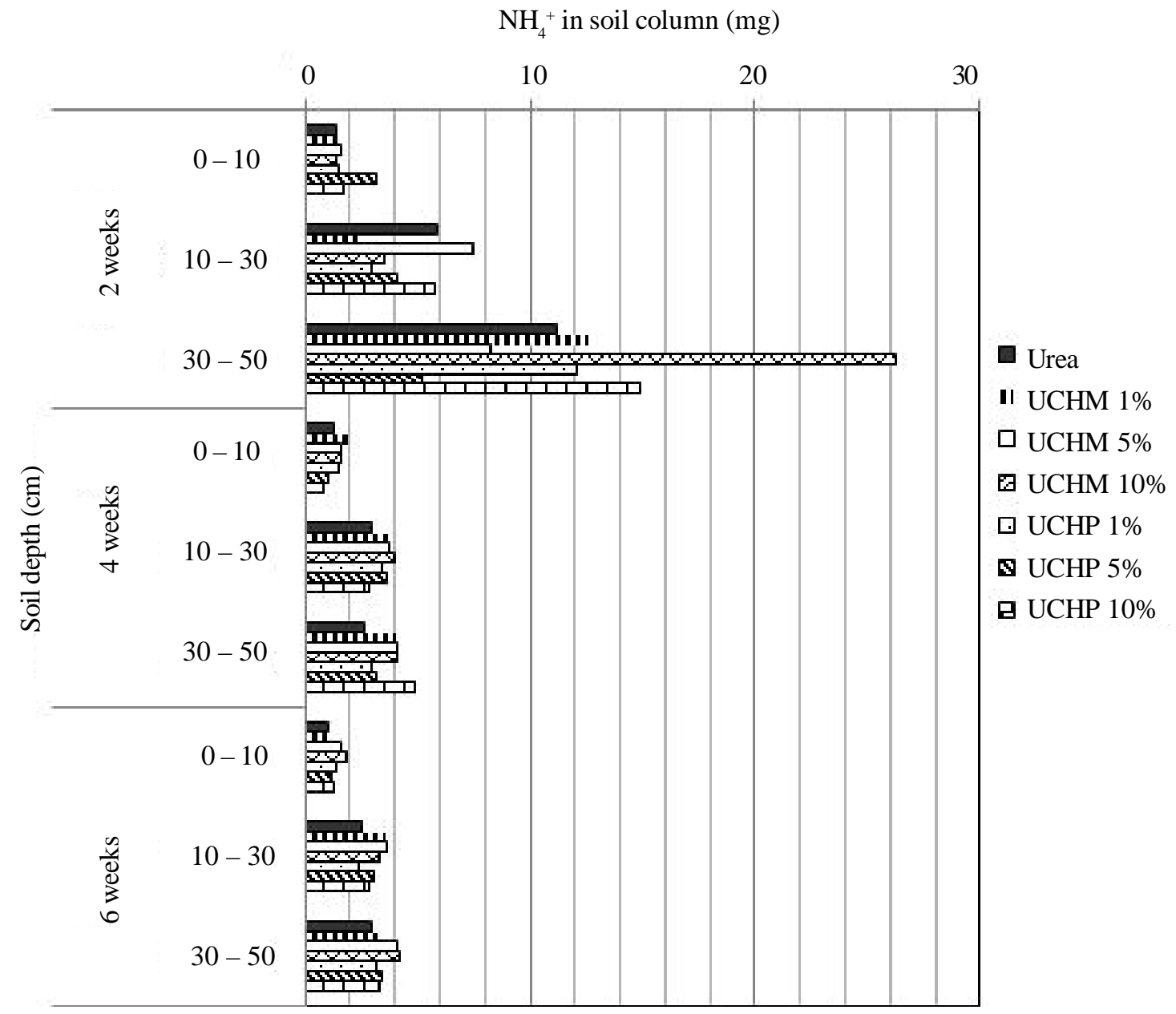

Figure 1. Distribution of $\mathrm{NH}_{4}^{+}-\mathrm{N}$ in soil column at 2, 4 and 6 incubation periods.

The distribution of $\mathrm{NO}_{3}^{-}-\mathrm{N}$ in all layers of the soil column under type of fertilizer treatments was similar at all incubation periods, but amount $\mathrm{NO}_{3}^{-}-\mathrm{N}$ was higher than $\mathrm{NH}_{4}^{+}-\mathrm{N}$. It indicated the leaching loss of $\mathrm{NO}_{3}^{-}-\mathrm{N}$ from soil column was lower than $\mathrm{NH}_{4}{ }^{+} \mathrm{N}$. At 6 weeks incubation period, it is shown that treatment UCHM $10 \%$ has content of $\mathrm{NO}_{3}^{-}-\mathrm{N}$ in $0-10 \mathrm{~cm}$ and $10-30 \mathrm{~cm}$ layers higher than other treatment. This suggests that UCHM $10 \%$ was slower leach than other fertilizers.
The highest nitrate content form is the nitrate from UCHM on 5\% concentration in $30-50 \mathrm{~cm}$ depth on 6 weeks incubation period. Vertical distribution (Figure 2) shows that nitrate content of urea coated with UCHM $10 \%$ is relatively higher than the other treatment. The nitrates content found on $0-10 \mathrm{~cm}$ depth, $10-30 \mathrm{~cm}$ depth and $30-50 \mathrm{~cm}$ depth respectively $6.55,14.50$ and $23.66 \mathrm{mg}$. This is a favorable condition for seasonal crop because their shallow root is able to reach and take $\mathrm{N}$ from soil. 


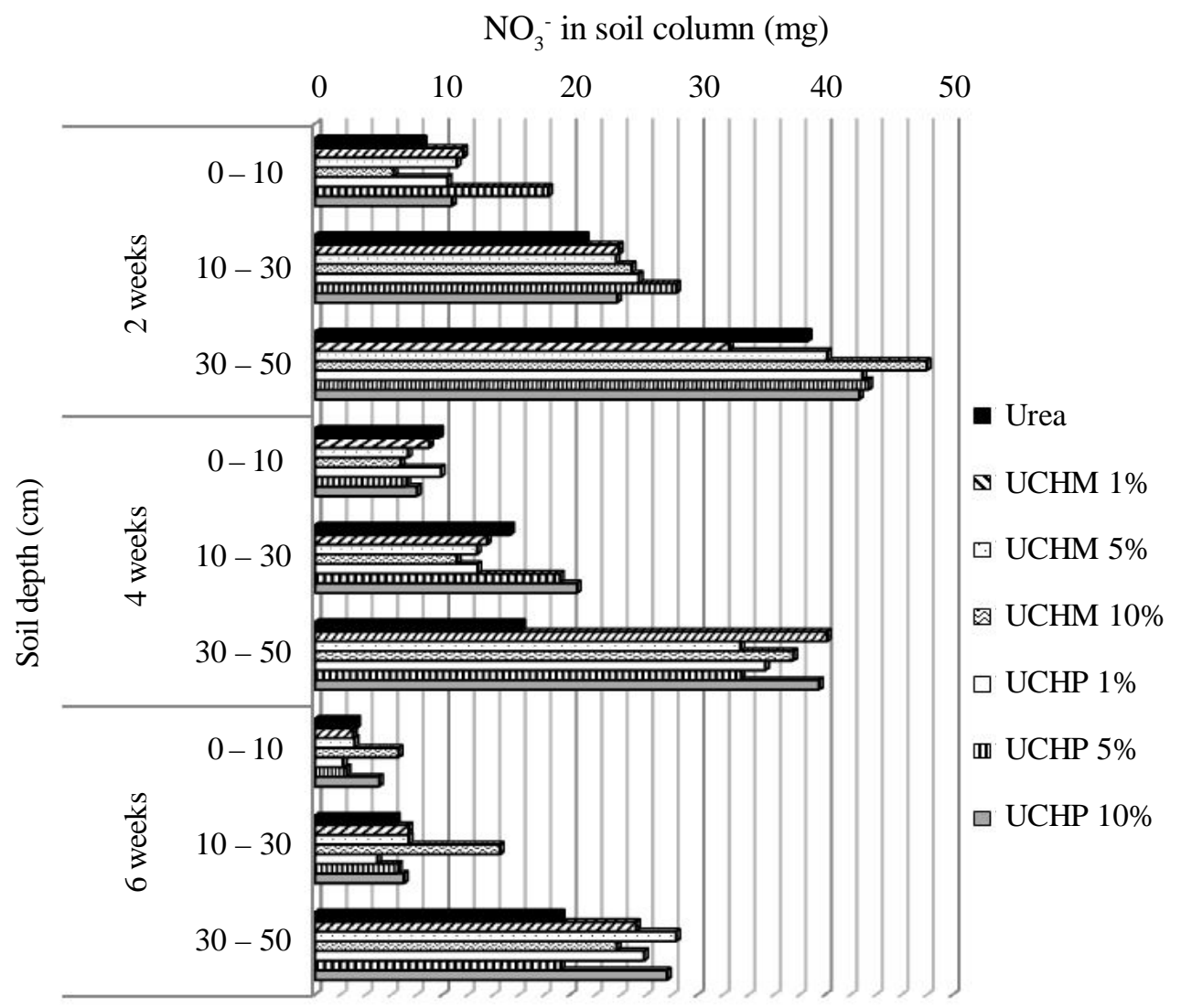

Figure 2. Distribution of $\mathrm{NH}_{4}{ }^{+} \mathrm{N}$ in soil column at 2, 4 and 6 incubation periods.

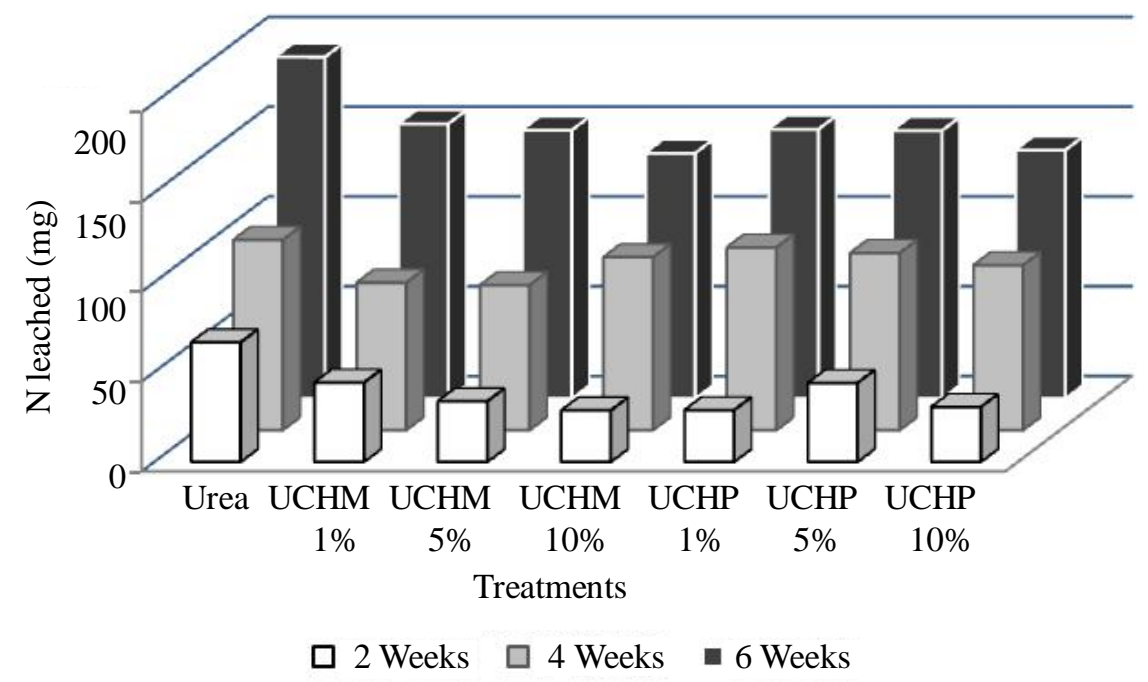

Figure 3. Effects of treatments on $\mathrm{N}$ leached from coastal sandy soil after 2, 4, and 6 weeks of incubation.

The alteration in the vertical distribution of $\mathrm{NH}_{4}^{+}-$ $\mathrm{N}$ and $\mathrm{NO}_{3}^{-}-\mathrm{N}$ in the soil column after fertilization reflects not only the movement of soil $\mathrm{N}$, but also the transformation of $\mathrm{N}$ fertilizer. The sum of $\mathrm{NH}_{4}{ }^{+} \mathrm{N}$ and $\mathrm{NO}_{3}^{-}-\mathrm{N}$ in soil column suggested the levels of mineral $\mathrm{N}$ in the soil. It seems that the mineral $\mathrm{N}$ in the soil decreased during the 6 weeks incubation period after applying urea and $\mathrm{UCH}$. The decreasing in $\mathrm{NH}_{4}{ }_{-}^{+}$ 
Table 3. Total $\mathrm{N}$ leaching over 2, 4 and 6 weeks of incubation and the reduction in $\mathrm{N}$ loss in comparison with the loss in urea (control).

\begin{tabular}{lcccccc}
\hline & \multicolumn{3}{c}{ Nitrate leached (mg) } & \multicolumn{4}{c}{$\begin{array}{c}\text { Reduction in total nitrogen } \\
\text { Treaching as compared to urea (\%) }\end{array}$} \\
\hline Urea & 2 weeks & 4 weeks & 6 weeks & 2 weeks & 4 weeks & 6 weeks \\
UCHM 1\% & $66.56 \mathrm{a}$ & $105.95 \mathrm{a}$ & $190.11 \mathrm{a}$ & None & None & None \\
UCHM 5\% & $44.19 \mathrm{~b}$ & $82.09 \mathrm{a}$ & $152.94 \mathrm{~b}$ & 33.62 & 22.52 & 19.55 \\
UCHM 10\% & $33.76 \mathrm{~b}$ & $80.74 \mathrm{a}$ & $149.38 \mathrm{~b}$ & 49.28 & 23.80 & 21.42 \\
UCHP 1\% & $28.65 \mathrm{~b}$ & $96.30 \mathrm{a}$ & $136.56 \mathrm{~b}$ & 56.97 & 9.11 & 28.17 \\
UCHP 5\% & $28.85 \mathrm{~b}$ & $101.75 \mathrm{a}$ & $149.91 \mathrm{~b}$ & 56.67 & 3.97 & 21.14 \\
UCHP 10\% & $43.97 \mathrm{~b}$ & $98.63 \mathrm{a}$ & $149.06 \mathrm{~b}$ & 33.94 & 6.91 & 21.59 \\
\hline
\end{tabular}

Note: Mean values with different letters are significantly different between treatments at $\mathrm{P} \leq 0.05$ using DMRT test.

$\mathrm{N}$ did not equal to an increasing in the amount of $\mathrm{NO}_{3}^{-}$ $-\mathrm{N}$ in the soil which indicating the probable loss of $\mathrm{NH}_{4}{ }^{+} \mathrm{N}$ from the soil column. Rosliza et al. (2009) found that ammonia loss from $\mathrm{N}$ fertilizer could occur in soil $\mathrm{pH}$ was 6.2 . Since the $\mathrm{pH}$ of the sandy soils used in this research was $6.7, \mathrm{~N}$ may have been lost from the soil due to volatilization.

\section{Leaching Loss of Fertilizer Nitrogen}

The effects of fertilizer type on $\mathrm{N}$ losses due to leaching during incubation in coastal sandy soil are shown in Figure 3. N leached from HCUM and HCUP was much lower compared to the urea (Figure 1). Incubation periods also had a strong effect on $\mathrm{N}$ lost due to leaching.

The total amount of $\mathrm{N}$ lost at the end of the study is shown in Table 3. All the treatments with UCHM and UCHP in significantly reduced $\mathrm{N}$ loss compared to urea alone. Nonetheless, UCHM $100 \%$ was less pronounced in reducing $\mathrm{N}$ leaching compared to other treatments. As a result, the total $\mathrm{N}$ loss was effectively reduced to $28.17 \%$ compared to the total loss in urea (Table 3).

The effect of urea coated with hucalci from several humic material on $\mathrm{N}$ leached can be seen in Table 3. In Table 3 shows that on 2 and 6 weeks incubation period, $\mathrm{N}$ leached on urea coated with hucalci both from manure and peat are significant different with non coated urea. The study found that the smallest $\mathrm{N}$ leached $(136.56 \mathrm{mg})$ on 6 weeks incubation period is in the column of urea coated with hucalci this result possible because humic calcium complex of UCHM is higher that UCHP, consequently the nitrate hold is much higher. In this case, calcium acts as Cation Bridge because of the two positive charges; one charge hold in Hs and the other charge hold nitrate. According to Marinsky et al. (1999), calcium ion binding to fulvic acid is modeled assuming formation of a monodentate carboxlate complex. Essington (2004) also found that $\mathrm{Ca}$ complexation by Hs formed a monodentate aliphatic carboxylate weak outersphere metal.

\section{CONCLUSIONS}

Based on the results of our experiment, it can be concluded that $\mathrm{N}$ leached in coastal sandy soil can be reduced with the application of accurate fertilizers. The study found that the urea coated humic-calcium from cow manure (UCHM) is better than urea coated humic-calcium from peat in decreasing $\mathrm{N}$ leached from coastal sandy soil.

\section{ACKNOWLEDGMENT}

The researchers acknowledge the financial support of this research by the Ministry of Higher Education, Indonesia by Doctoral Grant 2009.

\section{REFERENCES}

Ahmed OH, H Aminuddin and MHA Husni. 2006. Effects of urea, humic acid and phosphate interactions in fertilizer microsites on ammonia volatilization and soil ammonium and nitrate contents. Int J Agric Res 1: 25-31. 


\section{Sulakhudin et al.: Effect of Coated Urea with Humic-Calcium on Transformation of Nitrogen}

Al-Zahrani SM. 1999. Controlled-release of fertilizers: modelling and simulation. Int J Engineering Sci 37: 1299-1307.

Clinton PW, RH Newman, and RB Allen. 1995. Immobilization of $15 \mathrm{~N}$ in forest litter studied by $15 \mathrm{~N}$ CPMAS NMR spectroscopy. European J Soil Sci 46:551-556.

Cobena AS, HM Thomas, A Augusto, IM Juan, AD Jose and V Antonio. 2008. An inhibitor of urease activity effectively reduces ammonia emissions from soil treated with urea under Mediterranean conditions. Agric Ecos Environ 126(3-4): 243-249.

Essington ME. 2004. Soil and Water Chemistry: An integrative approach. CRC Press. Florida. 534 p.

Fageria NK. 2009. The use of nutrients in crop plants. Taylor \& Francis Group, LLC CRC Press. Boca Raton. 430 p.

Hazelton PA and B Murphy, 2007. Interpreting soil test results : what do all the numbers mean? [2 $2^{\text {nd }}$ ed.]. CSIRO Publishing. Collingwood VIC 3066 Australia. $152 \mathrm{p}$.

Huang PM and M Schnitzer. 1997. Interaction Soil Mineral, Natural Organik and Microbial. Elsevier. New York.

International Fertilizer Industry Association. 2006. Nitrogen Fertilizer Nutrient Consumption. at: http:// www.fertilizer.org/ifa/statistics/indicators/tablen.asp.

Kiran U and DD Patra. 2003. Medicinal and aromatic plant materials as nitrification inhibitors for augmenting yield and nitrogen uptake of Japanese mint (Mentha arvensis L. Var. Piperascens). Bioresource Tech 86: 267-276.

Lan W and M. Liu. 2008. Preparation and properties of chitosan-coated NPK compound fertilizer with controlled-release and water-retention. Carbohydrate Polymers 72: 240-247.

Lan W. M Liu and R Liang. 2008. Preparation and properties of a double-coated slow-release NPK compound fertilizer with superabsorbent and waterretention, Bioresource Tech 99: 547-554.

Marinsky JA, A Mathuthu, JH Ephrain and MM Reddy. 1999. Calcium ion binding to a soil fulvic acid using a Donnan Potential Model. Radiochem Acta 84: 205211.

Neinder R and DK Benbi. 2008. Carbon and nitrogen in the terrestrial environment. Springer Science. Germany. $430 \mathrm{p}$.

Oviasogie PO and PO Okolo. 2008. Effect of pH and concentration on the complexation of calcium ions with humic acid extracted from composted oil palm bunches. Inter J Phys Sci 3 (2): 056-058.
Pansu M and J Gautheyrou. 2006. Handbook of Soil Analysis: Mineralogical, Organic and Inorganic Methods. Springer-Verlag, Berlin Heidelberg New York. 993 p.

Patra DD, U Kiran, S Chand and M Anwar. 2009. Use of urea coated with natural products to inhibit urea hydrolysis and nitrification in soil. Biol Fertil Soils 45: 617-621 p. DOI 10.1007/s00374-009-0372-0.

Reeza AA, OH Ahmed, NMA Majid and MB Jalloh. 2009. Reducing Ammonia Loss from Urea by Mixing with Humic and Fulvic Acids Isolated from Coal. Am J Environ Sci 5 (3): 420-426.

Rocha JC, AH Rosa and M Furlan. 1998. An Alternative Metodology for the Extraction of Humic Substances from Organic Soils. J Brazilian Chem Soc 9 (1): 52-56.

Rosliza S, OH Ahmed and NMA Majid. 2009. Controlling Ammonia Volatilization by Mixing Urea with Humic Acid, Fulvic Acid, Triple Superphosphate and Muriate of Potash. Am J Environ Sci 5 (5): 605-609.

Sarkar D and AHaldar. 2005. Physical and chemical methods in soil analysis. New Age International (P) Ltd. New Delhi. 176 p.

Sharifi MR, FC Meinzer, ET Nilsen, PW Rundel, RA Virginia, WM Jarrell, DJ Herman and PC Clark. 1988. Effect of manipulation of water and nitrogen supplies on the quantitative phenology of Larrea tridentate (Creosote bush) in the Sonoran desert of California. Am J Bot 75: 1163-1174.

Tan KH. 1996. Soil Sampling, Preparation and Analysis. New York, Marcel Dekker, Inc, 408 p.

Tomaszewska M, J Anna and K Krzysztof. 2002. Physical and chemical characteristics of polymer coatings in CRF formulation. Desalination 146 (3): 19-323.

USDA. 2003. Key to soil taxonomy. Ninth Edition, 2003. Washington, DC. 332 p.

Yong CW, LZ Shun, MW Zhi, YF Han, QL Lai and ZW Run. 2009. Recovery of Residual Fertilizer-Nitrogen by Wheat in a Winter Wheat-Summer Maize Rotation in the North China Plain: A Soil Column Study. Agron J101: 925-932.

Zheng P. 1991. The Application and Production of Peat Humic Acids. Chemical Industry Press, Beijing.

Zhou JB, JG Xi, ZJ Chen and SX Li. 2006. Leaching and Transformation of Nitrogen Fertilizers in Soil after Application of $\mathrm{N}$ with Irrigation: A Soil Column Method. Pedosphere 16 (2): 245-252.

Zou HT, YS Wang, HW Song, YY Han, NYu, YLZhang, XL Dang, Y Huang and YL Zhang. 2009. The Production of Organic-Inorganic Compound Film-Coated Urea and the Characteristics of Its Nutrient Release. Agric Sci China 8 (6): 703-708. 